\title{
Overview of Wind Power Industry Value Chain Using Diamond Model: A Case Study from China
}

\author{
Jicheng Liu ${ }^{1,2}$, Qiushuang Wei ${ }^{1,2}$,*, Qiongjie Dai ${ }^{1,2}$ and Chunyan Liang ${ }^{1,2}$ \\ 1 School of Economics and Management, North China Electric Power University, Changping, \\ Beijing 102206, China; ljc29@163.com (J.L.); daiqiongjie06041@163.com (Q.D.); cyliang@ncepu.edu.cn (C.L.) \\ 2 Beijing Key Laboratory of New Energy and Low-Carbon Development, North China Electric Power \\ University, Changping, Beijing 102206, China \\ * Correspondence: 1172106033@ncepu.edu.cn; Tel.: +86-188-1055-2087
}

Received: 31 August 2018; Accepted: 8 October 2018; Published: 12 October 2018

check for updates

\begin{abstract}
Sustainable energy development has gained worldwide attention, in part thanks to the wind power industry value chain that focuses on overall value creation and innovation, especially in China. This paper aims to construct a wind power industry value chain model and comprehensively analyze factors that have significant influences on it using a modified diamond model, which has remained nebulous. Focused on the value-adding effect of constructed value chains, we offer key ideas from different angles. A factor condition lays the foundation of the value chain, and shows that China is experiencing energy structure adjustment in which wind power will play a key role; its resource potential is huge, but with mismatched distribution. Demand conditions reveal an increasing demand for wind but serious wind rejection as well; this is where the value-adding probability exists. Related and support departments collaborate to determine the overall value creation process. Firm strategy, structure, and rivalry are terms that describe possible value-adding subjects considering the wind industry as a whole. Government and opportunity provide robust prices and non-price policies to support value integration, and Technology is an effective factor in cost reduction and value creation as a high value-adding sector. Furthermore, a comparison of wind power industry value chains in China and Japan is conducted. Our findings underscore that a gap exists between actual performance and the expected wind power industry value chain, and corresponding measurements to promote the performance are discussed, including encouraging diversified business models, enhancing R\&D and independent innovation, professional cultivation, effectively reducing wind rejection rate, and the full range of government support.
\end{abstract}

Keywords: sustainability; value chain; wind power; diamond model; China

\section{Introduction}

The development and application of wind resources have become the world's strategic choice to solve environmental pollution, address the energy crisis, and obtain clean and cost-effective electric energy [1-5]. Wind power is one of the most promising sustainable energy sources, and has been rapidly developing in recent years [6]. The global cumulative installed capacity of wind energy has been growing at a rate of more than 19\% annually over the last decade [7]. Rapid development of wind power in China mainly depends on one condition, namely, abundant wind resources [8,9], and three driving factors, i.e., increasing attention on environmental issues, high oil prices, and rapid maturity of wind power technology. Based on the Wind Power on-grid Operation Situation of 2017 issued by the Chinese National Energy Administration (NEA), newly-installed on-grid capacity reached 15.03 million KW, and the cumulative capacity increased to 164 million $\mathrm{kW}$; generated electricity increased by $0.7 \%$, reaching 350.7 billion $\mathrm{kWh}$ [10]. 


\subsection{Motivation of the Paper}

After decades of development, China has formed a complete industrial chain, including raw material supply, components manufacturing, wind turbines, wind farms, power grids, end users, and supporting parts, such as technology, talent, institutions, and markets [11,12], as Figure 1 shows. Despite the development scale, it's noteworthy that the wind power industry in China is facing numerous challenges, including an extremely high wind curtailment situation [13-15], dependence on subsidy policy [16-20], imbalanced industry development [7,21], and an especially low overall value creation effect of the industrial chain. However, the global wind power industry is experiencing a key node of adjustment and reconstruction, and the development of renewable and sustainable energy technology makes it a more intensive, efficient, greener, and complicated value creation, transfer, delivery, and adding value chain system that aims to reduce non-value-adding operations as much as possible to realize a maximal conversion of value [22] and overall symbiosis effect instead of a simple pursuit of installed capacity performance, which arouses fundamental concern in view of the low value-adding efficiency of the current wind power industry from the perspective of value theory and overall competition. Motivated by the gap between the desirable value efficiency of expected wind power value chains, and the current situation compared to the potential value-adding capability, it becomes increasingly necessary to construct a wind power industry value chain model and launch a comprehensive analysis for it to increase overall value efficiency and provide corresponding value-adding suggestions. Another motivation of this paper is to enrich academic analyses about wind power industry value chains based on value theory, which is important but which has not been fully investigated in previous studies.

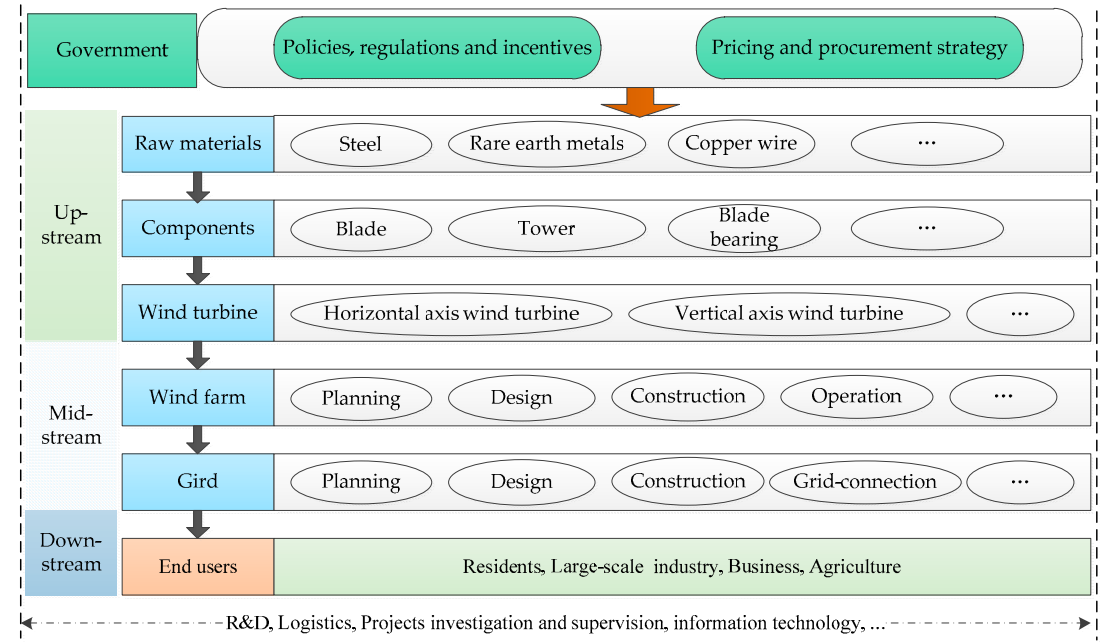

Figure 1. Structure of wind power industry chain.

\subsection{Literature Survey}

Current research about the wind power industry mainly focus on the following three research streams. The first tries to analyze its development status, existing problems, and solutions from various angles [7,15,18-20,23-28]. Yang et al. described the presentation of wind power in China considering its distribution, bases, installed capacity, power generation from the spatial perspective, and the environmental benefits [8]. Sahu presented an overview on current developments of wind energy, potentials, mismatching between the generating power, and installed capacities and future prospectus in China [29]. The second stream studies innovation and the improvement of key technologies to improve power generation, grid-connection, and wind-power consumption abilities [30-37]. Lina Alhmoud and Bingsen Wang reviewed the present situation of wind-energy reliability analyses [38]. Hung et al. proposed a probability-based dispatch strategy for determining energy storage capacity, with consideration of wind and load fluctuation, to improve acceptance of 
wind power in the grid [39]. Finally, the third stream analyzes the wind power industry from the aspects of industrial chains, and explores ways to increase its competitiveness [40,41]. Zhao et al. explored the dynamics of environmental turbulence and flexibility within the wind power industry chain, focusing on external factors of the industry, instead of internal factors or overall analysis [40]. They evaluated the wind power industry chain and examined its operation mechanism based on the supply, technological, and value chains, and indicated that China should change direction from emphasizing development speed to cultivating industry core competitiveness [11]. Cun-Bin Li et al. identified factors that affected the flexibility level of the wind power industry chain [12]. The first and the second kinds of literatures failed to analyze wind power from the perspective of the industry overall, while the third stream failed to launch a comprehensive analysis of the wind power industry chain, focusing on both its overall value creation improvement and factors influencing its value creation ability; all studies failed to comprehensively analyze and review wind power industry value chain in China with a diamond model both to enhance the overall value creation ability of the wind power industry, and to improve industrial sustainability. In addition, Zhao [28] studied the wind power industry using the diamond model with a traditional industrial development angle instead of a focus on the value chain. Liu [22] studied the value creation effect of the wind power industry value chain based on system dynamics, but ignored comprehensive analyses. Our literature survey shows that there is a gap in the academic field aimed at discussing wind power industry value chain in view of overall analyses via the diamond model.

To fill this gap, this paper focuses on a value chain analysis of wind power industry; it begins by constructing a value chain model and introducing the diamond model for comprehensive analysis. This model is suitable for analyzing the mutual influences between elements and their influences on the wind power industry; it has been widely used in industrial comprehensive analyses. Zhao [28] used a diamond model to understand the status quo of the Chinese wind power industry. Zhao [42] identified and analyzed, with the diamond model, factors that had significant impacts on the development of China's PV power industry. Wu [43] used the diamond model to analyze internal and external factors that had significant influences on the competitiveness of China's coal industry. The role of Multinational Enterprise (Mne) penetration and governance quality was studied with the diamond model by Fainshmidt [44]. Nam explored the success factors of the 'Night Markets' in Korea using the diamond model [45]. Kai Fang et al. effectively assessed national renewable energy competitiveness of the G20 with a revised diamond model [46]. Based on the wide application of the diamond model in comprehensive analyses of certain industries, we apply and modify it in analyzing the wind power industry value chain in China. In contrast to traditional diamond models, we modify it by considering Government, Opportunity, and Technology as dominant factors instead of accessory elements. Moreover, measurements of improving value creation and the innovation and symbiosis effects of the wind power value chain will be discussed.

\subsection{Contributions of the Paper}

This paper makes the following contributions. Firstly, we construct a wind power industry value chain model considering high value-adding sectors based on smiling curve theory. Apart from the traditional components of industry chains in China, power selling functions, demand side responses, diverse end users, and energy storage systems are included in our value chain model. Secondly, we analyze the wind power industry value chain in China with a modified diamond model, which has not been fully investigated in previous studies, in order to enrich the research on value theory in the wind power industry, and provide a new angle to describe China's wind power industry. It's noteworthy that the modified diamond model contains two analytical perspectives and dominant factors in China, namely, Government and opportunity, and Technology. Each aspect is precisely explored, making this paper different from traditional diamond model studies. Finally, we discuss wind power industry value chains in both China and Japan with a comparison analysis, and offer corresponding measurements to improve value creation and the innovation effect of the value chain to search for an overall symbiotic 
effect based. In general, the paper contributes to constructing and analyzing a novel wind power value chain to increase the overall value-adding effect with a modified diamond model, and to fill the gap in research with an overview of the wind power value chain in China.

\subsection{Organization of the Paper}

This paper is organized as follows. Section 2 explains the research framework of the paper with a schematic overview, and constructs a novel wind power industry value chain model focused on the value transfer and value-adding sectors during the conversion of raw materials to final products or services. It also analyzes the applied, modified diamond model. In Section 3, we launch a comprehensive analysis of the wind power industry value chain in China from five angles, namely (i) the Factor condition, (ii) Demand condition, (iii) Related and support departments, (iv) Firm strategies, structures and rivalries, and (v) Government and opportunity and Technology. According to the overview of the value chain in Section 3, Section 4 will provide a comparison analysis of value chains in Japan and China, and offer corresponding measurements to improve the overall value-adding effect of the wind power industry in China. Section 5 concludes our research.

\section{Methodology}

\subsection{Research Framework of the Paper}

Figure 2 shows our research framework. The research was designed with following aspects: (i) Discussion of the wind power industry in China with Michael Porter's value theory, and the creation of a novel value chain model considering all promising value-adding sectors. (ii) Exploration of a modified diamond model which is feasible and effective in investigating an overall analysis of the constructed value chain model. The diamond model is revised by taking Government, Opportunity, and Technology as dominant factors instead of accessory factors, and the modification is based on the actual situation of the wind power industry in China-which depends seriously on government subsidy and policy-and on the significant importance of related technologies in improving the value effect. (iii) Initiation of a comprehensive analysis of the value chain constructed with a modified diamond model from aspects of Factor conditions, Demand conditions, Related and support departments, Firm strategies, structures and rivalries, Government, Opportunity, and Technology. (iv) Present a comparison analysis with the wind power industry in Japan, and discusses corresponding suggestions for the chain regarding enhancing the overall value-adding effect of the wind power industry. Our purpose is to launch a comprehensive analysis and improve the overall value-adding effect of the wind power industry value chain in China, and to provide a novel and reasonable development angle.

\subsection{Wind Power Industry Value Chain Model Construction}

Most previous research has focused on the status quo, challenges, and development analyses of wind power from the perspective of global and national macroscopic policies and economics (as shown in Table 1). This paper describes and analyzes the internal structure and the value creation and innovation of the wind power industry value chain that clarifies the value transfer and value-adding process that occurs when converting raw materials to a final product or service [11]. According to the value theory of Michael Porter [47], value creation in a given industry is composed of a series of processes, including the basic activities and the supporting activities; the former is the key point of value creation of the wind power industry. Meanwhile, like technology-intensive industry, the value creation sectors can be described with the smiling curve (see Figure 3), which reveals the high value-adding sectors in the research and development stage and the after-service stage of the wind power industry that should be taken into account in the value chain model's construction. 


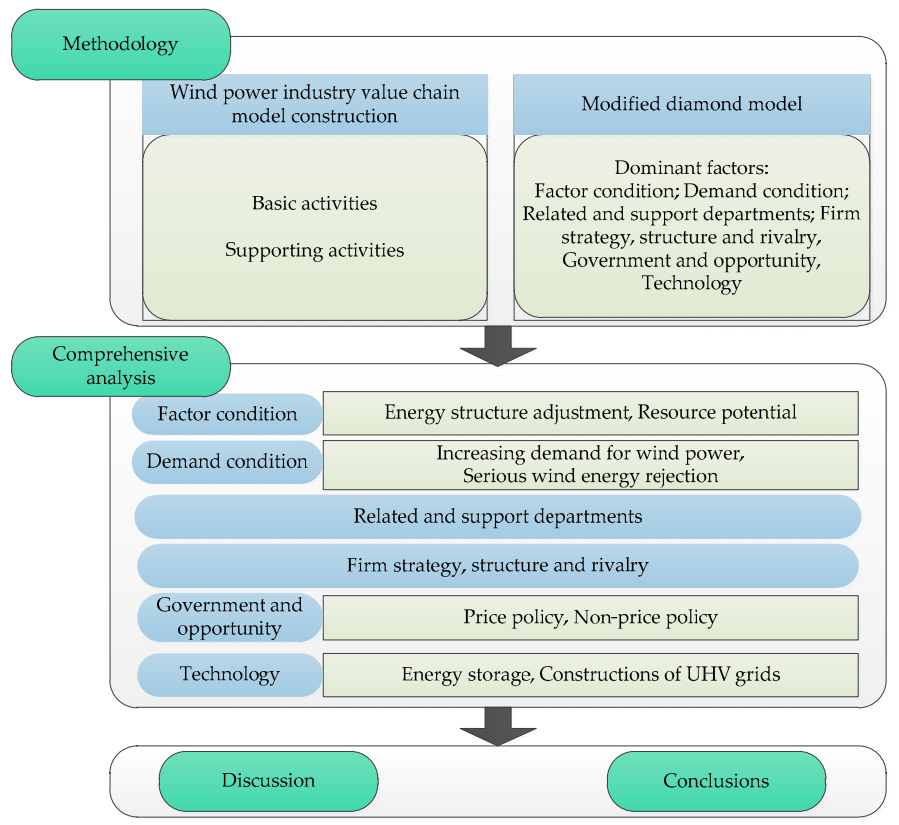

Figure 2. Schematic overview of the paper.

Table 1. Main previous works focused on wind power industry analysis.

\begin{tabular}{|c|c|c|}
\hline Papers & Objects & Methods/Contents \\
\hline [11] & $\begin{array}{l}\text { Wind power industry chain } \\
\text { in China }\end{array}$ & $\begin{array}{l}\text { Wind power supply chain; technology chain; } \\
\text { description of value chain. }\end{array}$ \\
\hline [16] & $\begin{array}{l}\text { Large scale wind } \\
\text { power integration }\end{array}$ & $\begin{array}{l}\text { Challenges of large-scale wind power integration in } \\
\text { China; policies analysis. }\end{array}$ \\
\hline [48] & $\begin{array}{l}\text { Wind power generation and } \\
\text { electricity price }\end{array}$ & $\begin{array}{l}\text { Relationship between wind power generation and } \\
\text { electricity price behavior in Germany }\end{array}$ \\
\hline [13] & Industrial performance analysis & $\begin{array}{l}\text { Status quo; development process of wind power } \\
\text { feed-in tariff; performance analysis. }\end{array}$ \\
\hline [49] & Wind power prediction & Hybrid model (LSSVM-GSA); prediction; simulation. \\
\hline [50] & Wind power forecasting & $\begin{array}{l}\text { Prediction intervals (PIs) to capture the uncertainty } \\
\text { associated with wind power generation. }\end{array}$ \\
\hline [51] & $\begin{array}{l}\text { Wind speed description and } \\
\text { power density in northern Spain }\end{array}$ & $\begin{array}{l}\text { Wind speed analysis; wind power density; wind } \\
\text { resources and wind turbine application. }\end{array}$ \\
\hline [52] & $\begin{array}{l}\text { Wind power; economic rational; } \\
\text { environment issues }\end{array}$ & $\begin{array}{l}\text { Economic rational, environment impacts and cost } \\
\text { issues of wind power. }\end{array}$ \\
\hline
\end{tabular}

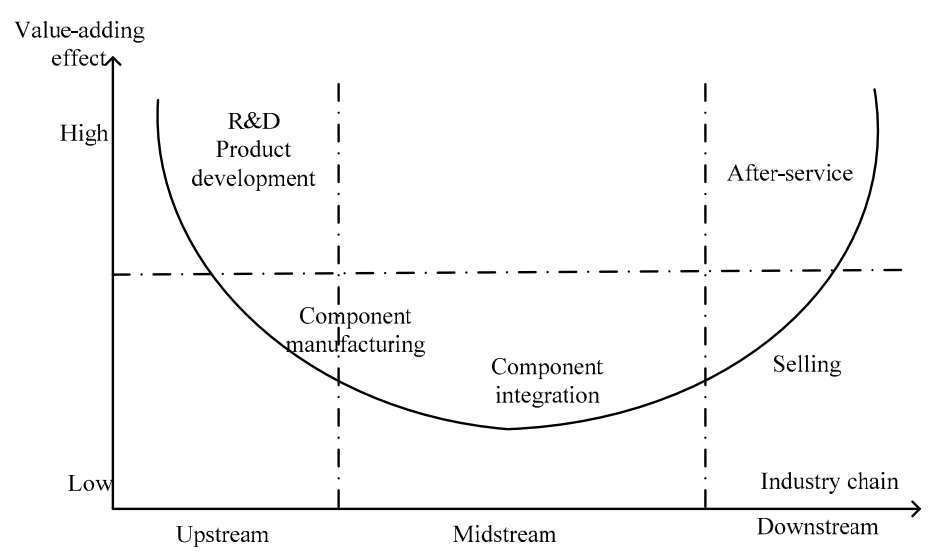

Figure 3. Smiling Curve of wind power industry. 
After decades of wind power development, China's cumulative installed capacity of wind power increased rapidly, from $2537 \mathrm{MW}$ in 2006 to 178,260 MW in 2017, as shown in Figure 4. However, the high value-adding sectors develop slowly because much attention is paid to wind turbines and component manufacturing, instead of value creation and innovation abilities for the whole industry chain. Every wind power enterprise that wants to achieve and maintain its competitive advantage should focus on both its inner value chain and that of the whole wind power industry. Meanwhile, the traditional industry chain does not demonstrate much industrial flexibility and structure plasticity [22]. As such, we need to construct a wind power industry value chain considering the dynamic development conditions of wind power in China and the changing environment. On this basis, this paper constructs the wind power industry value chain model as shown in Figure 5. The value chain model determines the following basic activities and supporting activities of the wind power industry: (i) The former is composed of power generation (raw material supply, equipment manufacture, overall wind turbine assembly, wind farm construction and operation), power transmission (gird), power selling, power use and servicing, and end users. (ii) The latter consists of procurement, research and development, human resources, policies and regulations, taxation, and other related activities. This paper will launch an exhaustive analysis of the value creation and innovation effect of the wind power industry in the following sections, based on the constructed value chain model.

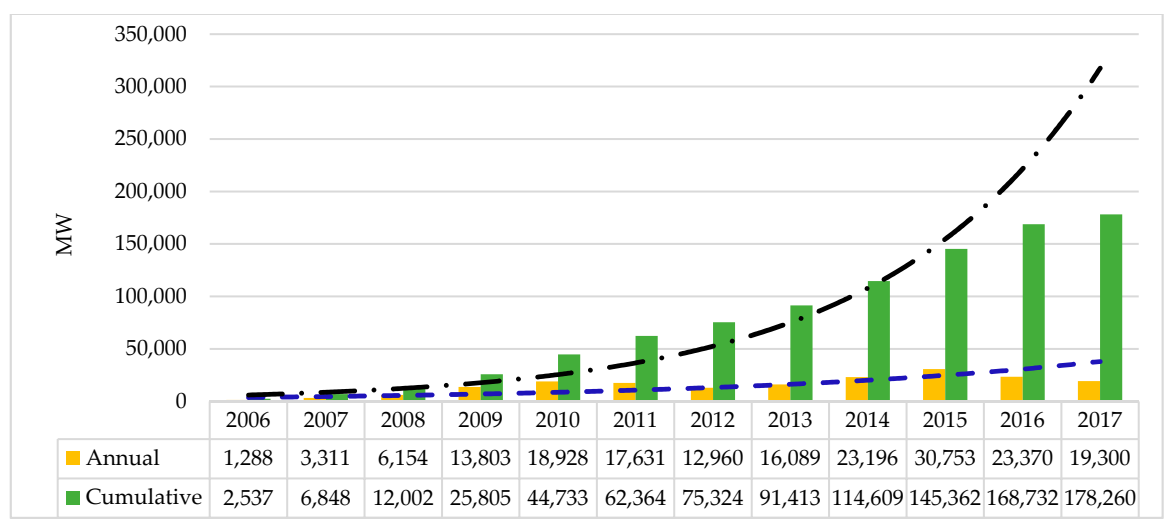

Figure 4. Annual and cumulative installed capacity of wind power in China $[8,17,53]$.

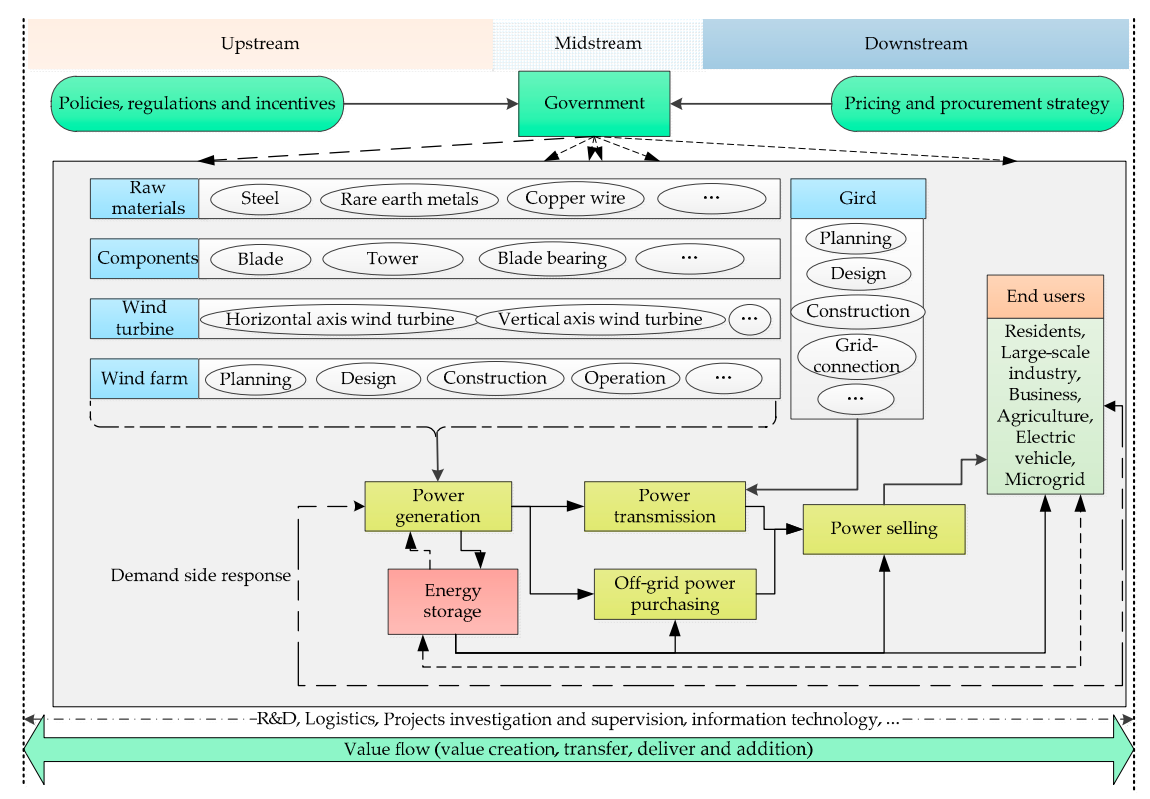

Figure 5. Wind power industry value chain model. 


\subsection{Diamond Model}

To fully describe the value creation and innovation effect of the value chain model constructed above, we use the diamond model for a systematic and comprehensive analysis. A diamond model has four major components, namely, the Factor condition, the Demand condition, Related and support departments, Firm strategies, structures and rivalries, as well as the accessory factors, Government and Opportunity $[42,43,54-56]$. Compared with traditional diamond models which consider Government and Opportunity as accessory factors, the analysis structure of the diamond model used in this paper (see Figure 6) takes Government, Opportunity, and Technology as additional dominant factors, because they play extremely significant roles in the development of the Chinese wind power industry. Among these factors, the Factor condition refers to initial wind power industrial resources, i.e., natural wind resources, energy structures, etc. The Demand condition is current and future domestic wind power demand, and it is the motivating force behind industrial development, and the basis of value creation and innovation. Related and support departments are those that contribute to the wind power industry value chain. Firm strategies, structures, and rivalries represent the wind power investment and development context and rules, the industrial environment, and competition [8]. Considering how influential the Government, Opportunity, and Technology are for the wind power industry in China, we will consider them as the dominant factors of the value chain.

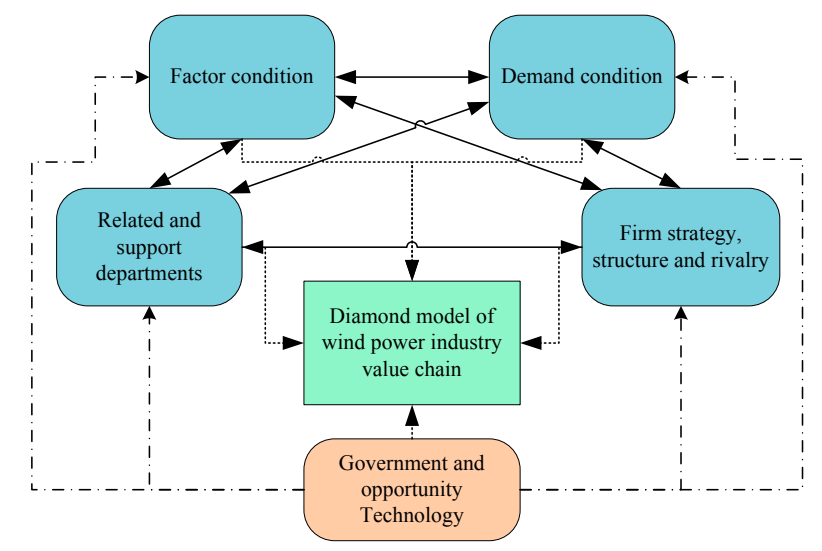

Figure 6. Diamond model of the wind power industry value chain analysis.

\section{Comprehensive Analysis Using Diamond Model}

\subsection{Factor Condition}

The Factor condition refers to factors contributing to the value creation effect of the wind power industry which act as the key determinants of the level that the value chain can sustain over time [56]. This section consists of the energy structure and resource potential of wind power.

\subsubsection{Energy Structure Adjustment}

China's energy consumption has experienced rapid growth over the past three decades, raising great concerns for its energy consumption structure adjustment [57]. Even though the renewable energy proportion in China needs improvement, it's developing with a high ratio, as shown in Figure 7. According to BP Statistics Review of World Energy 2017 [58], global renewable power generation (excluding hydropower) increased by $14.1 \%$ in 2016, and more than half of that growth stemmed from wind power. The Chinese government highlights energy strategy transfer and energy structure adjustment to improve renewable energy adoption, and to reduce reliance on fossil energy and pressures on the environment. In the Chinese energy structure adjustment, wind power will play a critical role in the future; its magnitude of generated electricity reached $3057 \times 10^{8} \mathrm{kWh}$, with a high growth rate of $27 \%$ in 2017, while the figure for 2012 was only $1004 \times 10^{8} \mathrm{kWh}$. 


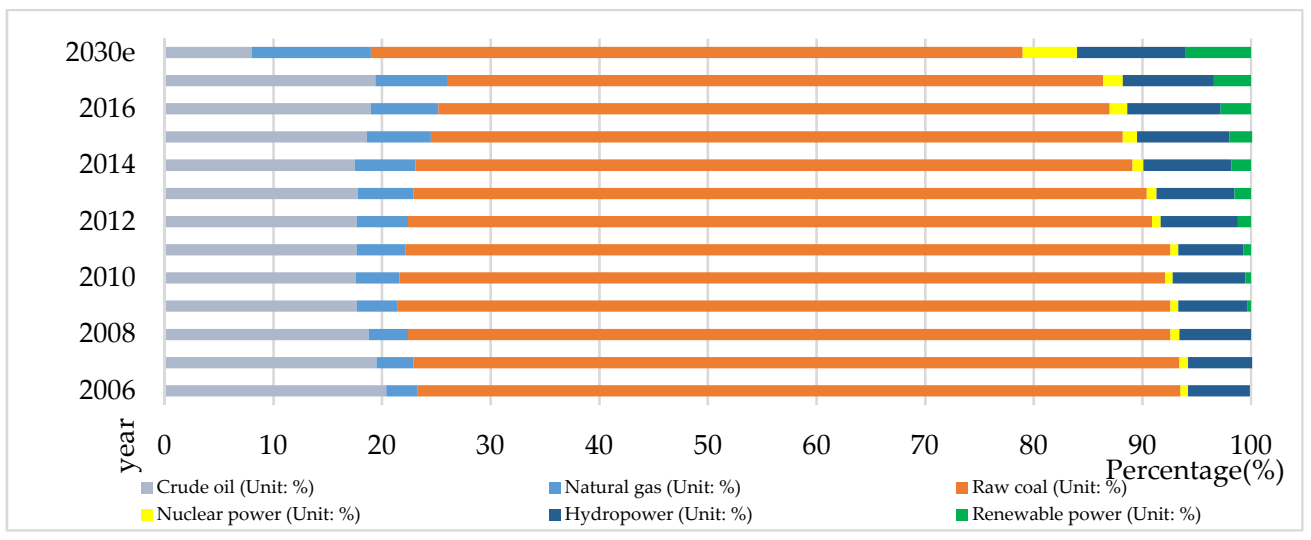

Figure 7. Energy structure during 2006-2017. Data source: BP Statistical Review of World Energy 2017 [58]; BP Statistical Review of World Energy 2018 [59]; Energy production and consumption reform strategy (2016-2030) [60]; Chinese industry information (2016) [61].

\subsubsection{Resource Potential}

Resource optimization is one key purpose of value creation and innovation in the wind power industry. Wind power resources in China are characterized by two significant labels, namely rich wind resource potential, and uneven resource and electricity load distribution. The former is mainly distributed in the "Three-Norths" areas, while the latter is located in coastal cities thousand miles away, as shown in Figure 8. The "Three-Norths" areas occupy above $90 \%$ of wind resources of China, including Xinjiang Autonomous Region and Gansu province in northeast China, Heilongjiang, Jilin, Liaoning provinces in north China, and Hebei province, Inner Mongolia Autonomous Region in northwest China The cumulative installed capacity of wind power in the aforementioned areas is shown in Figure 8. Meanwhile, China has established eight 10-GW bases for the improvement of wind power development (see Figure 8); they are located in Xinjiang, Gansu, West Inner Mongolia, East Inner Mongolia, Hebei, Jilin, Shandong, and Jiangsu.

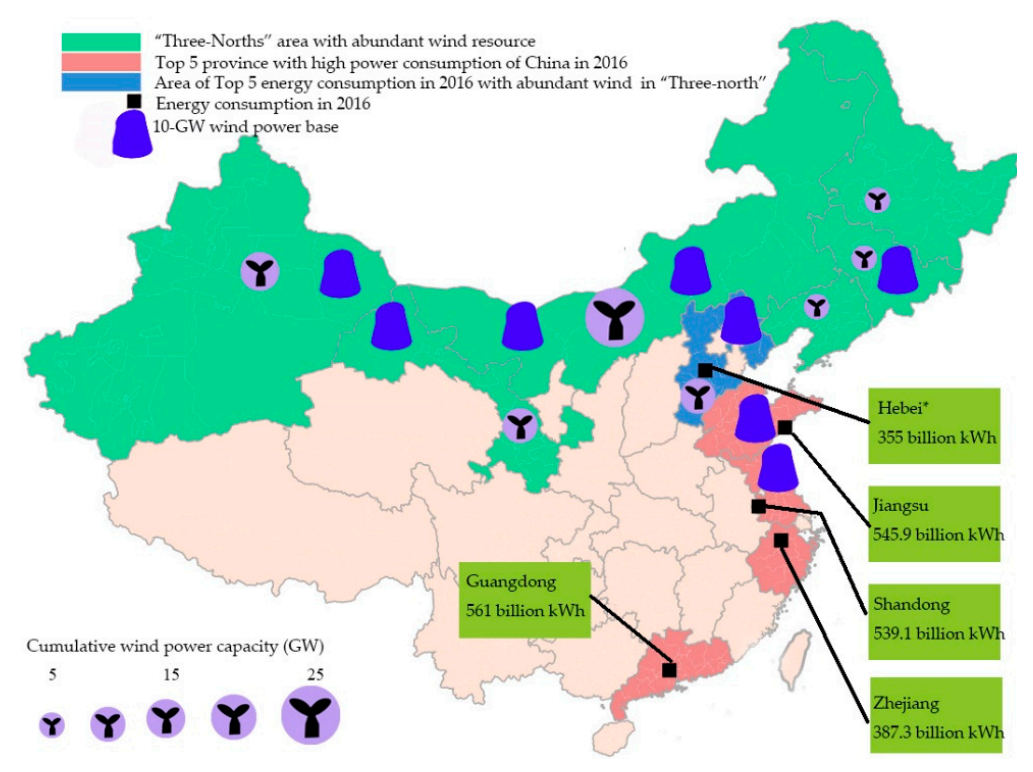

Figure 8. Wind resource and energy consumption distribution in China (Data source: location data of 10-GW wind power base is based on [24], data of cumulative installed capacity is integrated by [62] and Chinese Wind Power, data of energy consumption is collected from statistical data from the corresponding Provincial Bureau of Statistics. Magnitude of energy consumption of Hebei is predicted with data from January and August, 2016). 


\subsection{Demand Condition}

\subsubsection{Increasing Demand for Wind Power}

Sustainable and stable market demand is the driving force of power development. The wind power industry needs to satisfy the quality and quantity requirements of end users in the value chain to improve its competitiveness by providing renewable and clean electricity, thereby achieving the value creation and innovation effect. We will describe the demand condition from the perspective of the overall electricity demand market and the wind power demand condition. Along with the social and economic development, electricity demand in China has increased at a high rate in recent years (see Figure 9). Meanwhile, The Thirteenthe Five-Year Plan for Wind Power Development ([2016] No. 314) [63], issued in 2016, determined the following medium- and long-term development purposes: (i) $15 \%$ and $20 \%$ of non-fossil energy consumption proportions by 2020 and 2030 in China. (ii) 210,000 MW of cumulative on-grid installed capacity of wind power by 2020, including $5000 \mathrm{MW}$ of cumulative on-grid installed capacity of offshore wind power. (iii) 420 billion $\mathrm{kWh}$ of annual electricity generated by wind power, and $6 \%$ of the proportion in annual total power generation. This plan guarantees the demand of wind power at a national level, and lays the foundation for value integration of the whole wind power value chain.

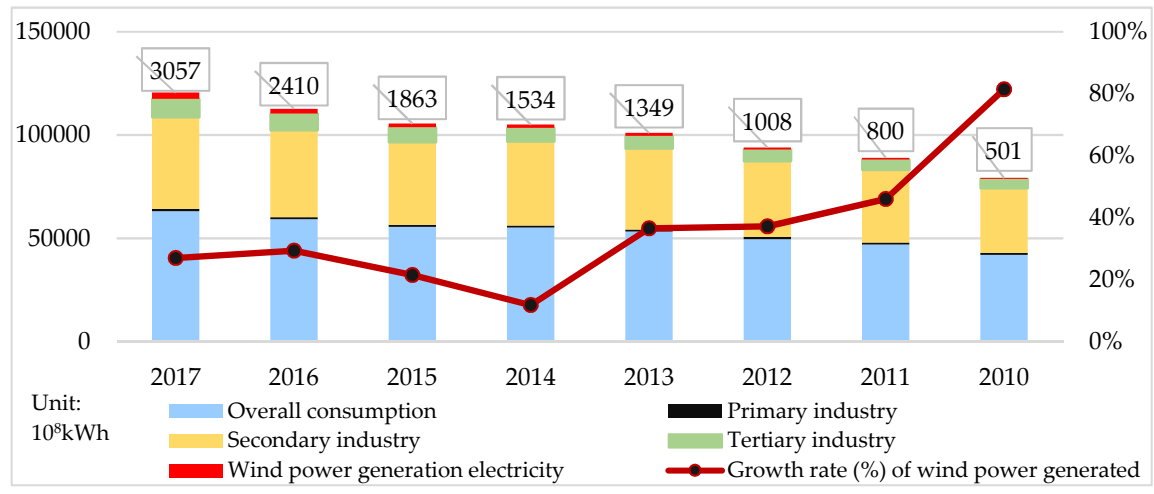

Figure 9. Energy consumption structure and wind power generation electricity of China during 2010-2017. (Data in the label refers to magnitude of wind power generation electricity and the data is collected and integrated with references $[8,64,65]$ and NEA).

\subsubsection{Serious Wind Energy Rejection}

Although market demand is encouraged and developed with favorable conditions for wind power, its growth rate is severely restricted by the serious wind energy rejection situation which has occurred in most areas of China. Wind energy rejection is defined as the total amount of the electrical energy which could be generated by the wind turbines according to the wind resources, but which is dropped by the wind farms due to the limits of the electrical transmission lines or potential safety problems in the electric power grid [14]. The wind energy rejection rate of China in 2016 was 21\%, its highest recorded levels. The top three areas were Gansu, Xinjiang, and Inner Mongolia, whose rejection rates and quantities were respectively $43 \%$ and 10.4 billion $\mathrm{kWh}, 38 \%$ and 13.7 billion $\mathrm{kWh}$, $30 \%$, and 0.29 billion $\mathrm{kWh}$. Figure 10 shows the wind power generation and rejection situation in China in 2010-2017, and the rejection situation of the "Three-north" areas in 2011-2017. Figure 11 shows areas and their corresponding rejection rates in 2017. From the angle of the overall value creation effect of value chain, power rejection reflects wind resource waste and value loss of the whole value chain. One major reason for this phenomenon in China is that randomness and fluctuation of wind energy generation might pose serious problems on the current power grid; thus, a great deal of wind energy was rejected. At present, policies and plans are issued to reduce the wind energy rejection rate. Based on the Implementation Plan of Solving Water/Wind/Solar Power Rejection Problems, issued on 
Nov. 14, 2017, the restriction purposes of maximum rejection rates are respectively 30\% for Gansu and Xinjiang, 20\% for Jilin, Heilongjiang and Inner Mongolia, and 10\% for rest areas in China.

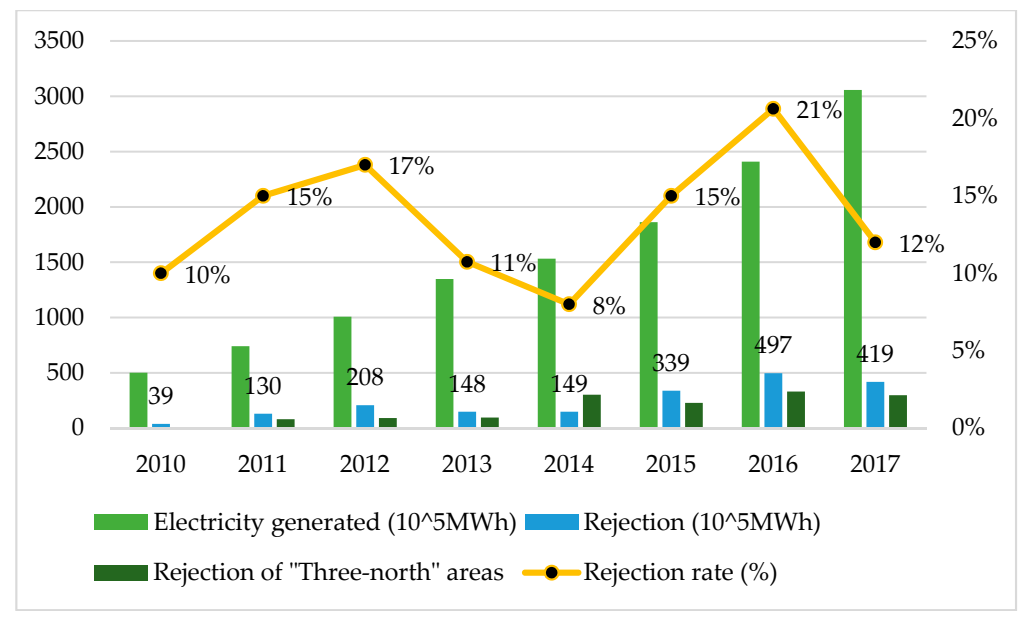

Figure 10. Wind power generation and rejection situation in China in 2010-2017. (Data source: the electricity generated data and rejection data of 2010 to 2012 was from [4,14]. From this, the corresponding rejection rate was calculated, and we modified partial data from the Electricity Regulatory Annual Report 2010 reported by China's Central People's Government [66]. Other electricity generated data and rejection data are collected from the annual wind power development report from the website of NEA. Data regarding the rejection rates of the "Three-north" areas are integrated from $[10,62,67-69])$.

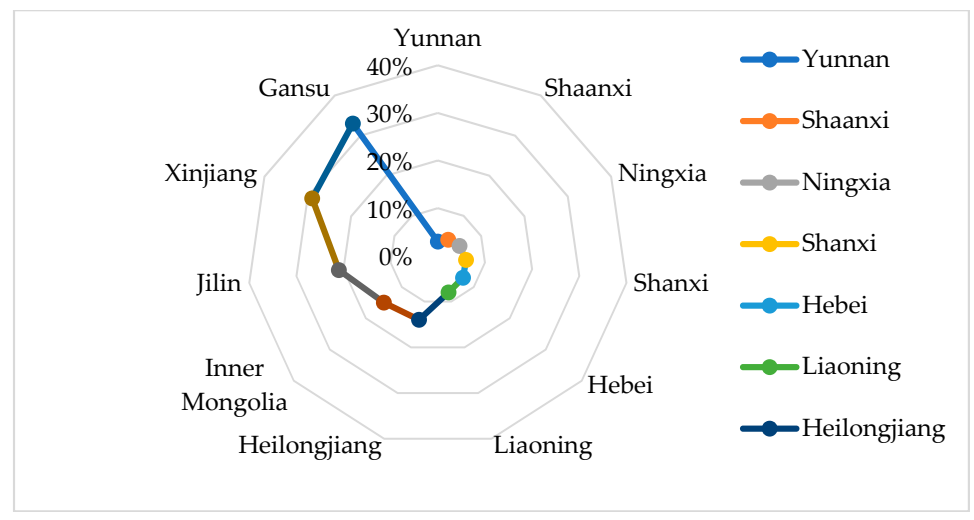

Figure 11. Areas and corresponding rejection rates in 2017. (Data source: [70] and annual wind power development report 2017 in website of NEA).

\subsection{Related and Support Departments}

The value creation and innovation of the whole value chain depends on collaboration between various departments. From the prospect of wind turbines and components manufacturing, even though it lies in the low value-adding section of smiling curve, Chinese wind equipment manufacturing has made significant achievements, and has contributed to wind power globally to a large extend despite the fact that this industry in China is at its initial stage of development. The capacity of newly-installed wind power in China reached $1966 \mathrm{MW}$ in 2017, of which $72.8 \%$ came from the top 6 manufacturing firms, as outlined in Figure 12. As for Chinese grid construction, uneven distribution between wind resource and cities with heavy loads gives rise to long-distance grid construction demand, but current grid construction in China is primarily designed for traditional power generation instead of renewable energy generation. Considering long-term wind energy consumption requirements, long-distance and ultra-high voltage (UHV) power transmission are discussed in various government reports. More details about UHV power transmission is provided in Section 3.6.2. 


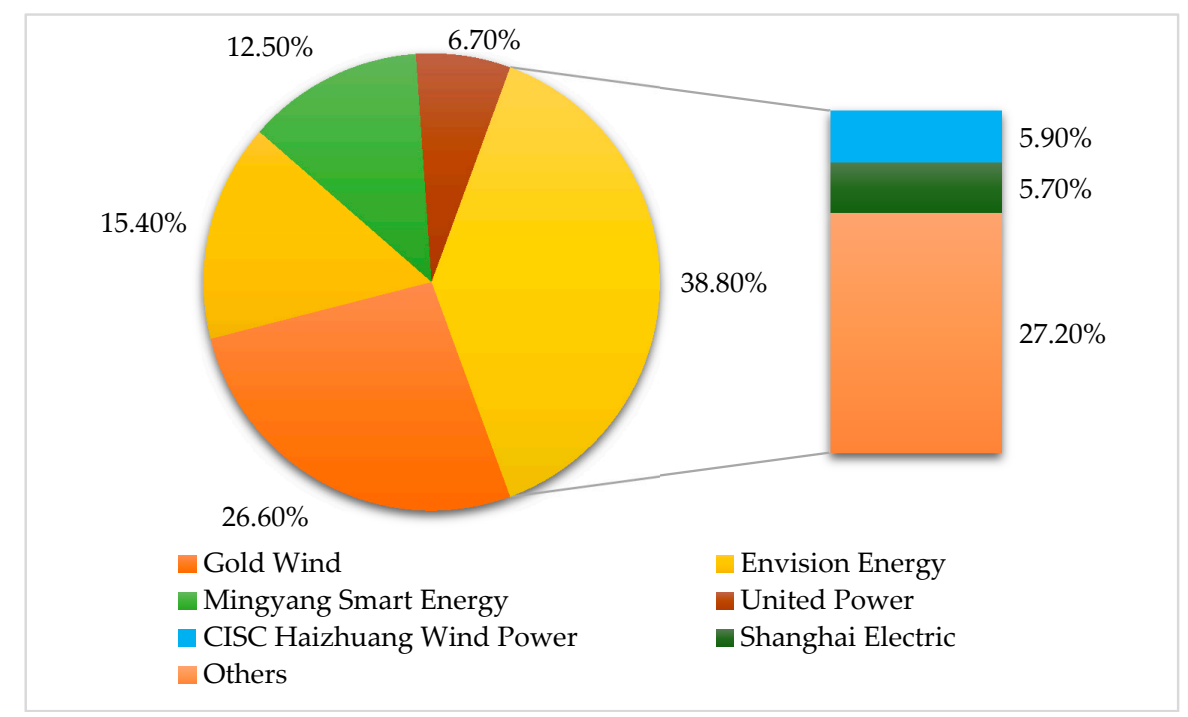

Figure 12. Wind turbine manufacturing of China in 2017 [71].

Increment power distribution subjects, energy storage (ES) subjects, and power selling subjects have undergone rapid development, although all of them are immature compared with power markets in foreign developed countries. Among them, the first second batches of pilot increment power distribution includes 106 and 89 projects, respectively, determined by National Development and Reform Commission (NDRC) and NEA [72,73] in 2016 and 2017. As for ES subjects, the statistics in Figure 13 show that income from ES businesses of the top 500 world new energy enterprises increased at an extremely high rate from 2011 to 2016.

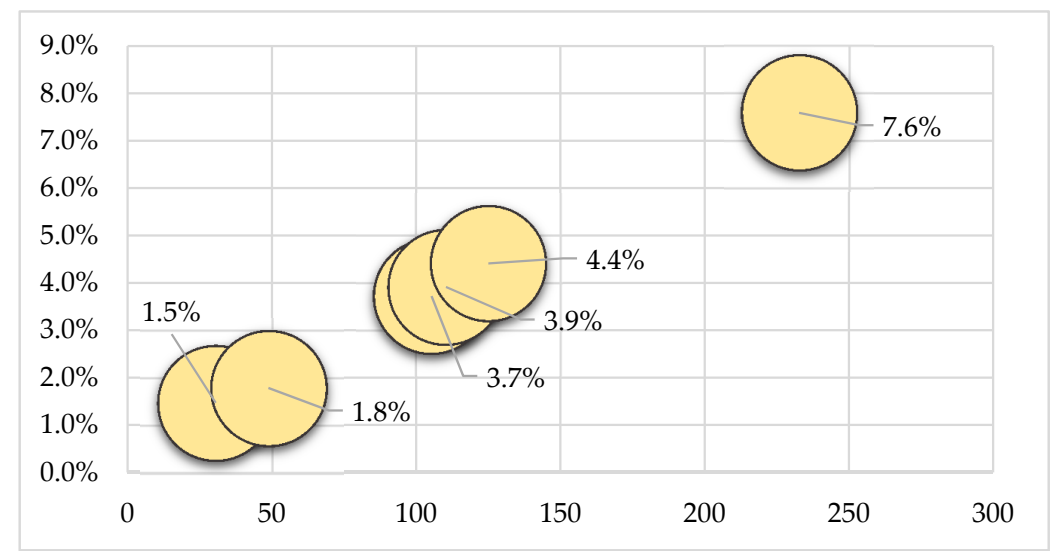

Figure 13. Incomes of top 500 world new energy enterprises in 2011-2016 (Unit: billion yuan) [74].

\subsection{Firm Strategy, Structure and Rivalry}

The wind power industry in China is dominated by three kinds of firms, namely: industrial leaders, traditional wind equipment manufactures, and wind power generation firms [75]. This paper describes the strategies, structures, and rivalries of wind power firms following the value chain route shown in Figure 14. In order to further deepen the efficiency of the power system, the State Council [76] pointed out that China would liberalize electricity prices in an orderly manner, excluding transmission and distribution systems, open the power selling business to social capital, and liberalize power generation plans, except for public welfare and regulatory ones. On this basis, more and more social capital is being invested in the power distribution and selling industries, thus enhancing the market's competitiveness and effectiveness, and increasing overall value creation and the innovation effect. 


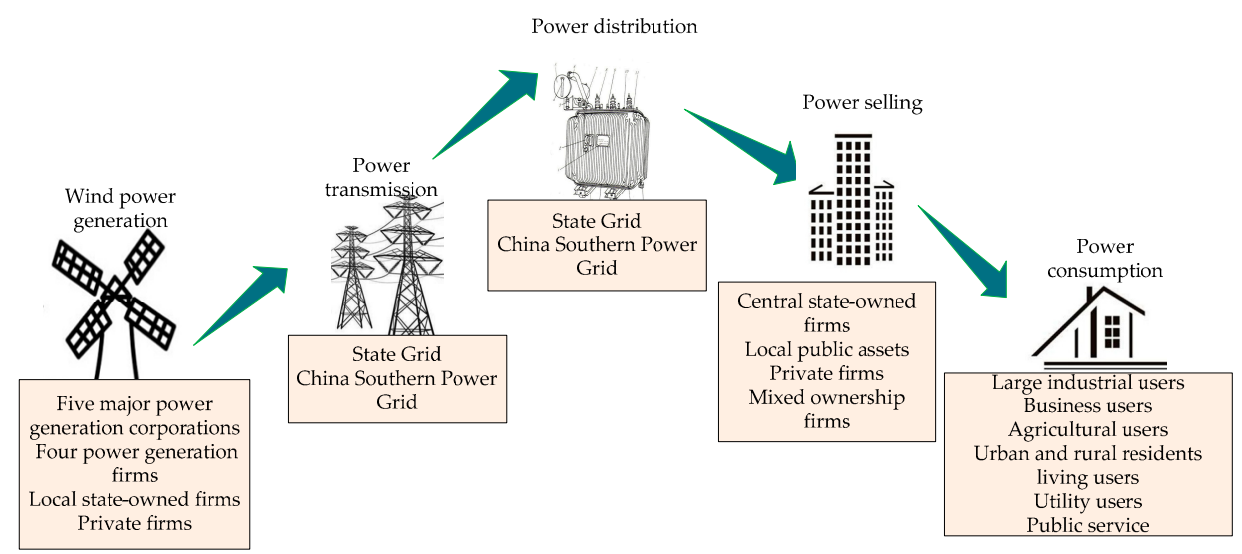

Figure 14. Firm strategy, structure and rivalry of wind power industry.

\subsection{Government and Opportunity}

The government acts as the leader and supervisor of wind power development and encourages the wind power industry to achieve higher levels of competitive performance and regulate renewable power market operations. Support from the government has a positive impact on the value chain of the wind power industry [11], and is essential to increase value creation and the innovation effect. The Chinese government has published a series of policies, which can be divided into price and non-price policies. Price policy refers to the policy that clearly determines wind power prices as opposed to quantities; the non-price policy doesn't directly decide the wind power price, but regulates the power market by other means.

\subsubsection{Price Policy}

As for the price policy, NDRC determined the benchmark price of onshore wind power in 2009 and adjusted it in 2015, as Table 2 shows. Meanwhile, benchmark prices for offshore wind power and intertidal zone wind power were determined as well: 0.85 yuan $/ \mathrm{kWh}$ and $0.75 \mathrm{yuan} / \mathrm{kWh}$, respectively. However, the prices of projects approved in and after 2017 would be calculated with accurate cost data.

Table 2. Benchmark price of onshore wind power in China during 2014-2018.

\begin{tabular}{|c|c|c|c|c|c|}
\hline \multirow{2}{*}{ Category } & \multirow{2}{*}{ Area } & \multicolumn{4}{|c|}{ Benchmark Price (Unit: yuan/kWh) } \\
\hline & & 2009-2014 & 2015 & 2016-2017 & 2018 \\
\hline I & $\begin{array}{l}\text { Inner Mongolia except Chifeng, Tongliao, Xing'an League and Hulun } \\
\text { Buir; Urumqi, Ili, Karamay, Shihezi of Xinjiang }\end{array}$ & 0.51 & 0.49 & 0.47 & 0.40 \\
\hline II & $\begin{array}{l}\text { Zhangjiakou and Chengde of Hebei Province; Chifeng, Tongliao, } \\
\text { Xing'an League and Hulun Buir of Inner Mongolia; Jiayuguan and } \\
\text { Jiuquan of Gansu province; Yunnan Province }\end{array}$ & 0.54 & 0.52 & 0.50 & 0.45 \\
\hline III & $\begin{array}{l}\text { Baicheng and Songyuan of Jilin Province; Jixi, Shuangyashan, Qitaihe, } \\
\text { Suihua, Yichun and Daxinganling area of Jilin province; Gansu } \\
\text { Province except Jiayuguan and Jiuquan; Xinjiang except Urumqi, Ili, } \\
\text { Karamay and Shihezi; Ningxia }\end{array}$ & 0.58 & 0.56 & 0.54 & 0.49 \\
\hline IV & Other areas in China & 0.61 & 0.61 & 0.60 & 0.57 \\
\hline
\end{tabular}

Data source: NDRC.

\subsubsection{Non-Price Policy}

Non-price policy includes two kinds of policy tools, namely: macro-level policy tool and financial \& tax incentives. Macro-level policies directly set the development targets of renewable energy and wind power development, and conduct the power market development direction (see Table 3), while financial \& tax incentives determine the investment support and taxation preferences/exemptions for the wind power industry (see Table 4). 
Table 3. Macro level policies of wind power in China.

\begin{tabular}{|c|c|c|}
\hline Macro Level Policies & Year & Key Points \\
\hline $\begin{array}{l}\text { Medium and Long-term Development Plan of } \\
\text { Renewable Energy }\end{array}$ & 2007 & $\begin{array}{l}\text { Cumulative installed capacity of wind power should reach } \\
30 \text { million } \mathrm{kW} \text { by } 2020\end{array}$ \\
\hline Renewable Energy Law Amendment & 2010 & $\begin{array}{l}\text { Full amount indemnificatory acquisition system of renewable } \\
\text { power generation }\end{array}$ \\
\hline $\begin{array}{l}\text { Thirteen Five-year Plan of National Strategic } \\
\text { Emerging Industry Development }\end{array}$ & 2016 & $\begin{array}{l}\text { Promoting high quality wind power development and } \\
\text { utilization; Building technical test and industrial supervision } \\
\text { public service platform of wind power }\end{array}$ \\
\hline Thirteen Five-year Plan of Wind Power & 2016 & $\begin{array}{l}\text { By the end of } 2020,0.21 \text { billion } \mathrm{kW} \text { of cumulative installed } \\
\text { capacity and } 420 \text { billion } \mathrm{kWh} \text { of annual power generation of } \\
\text { wind power }\end{array}$ \\
\hline $\begin{array}{l}\text { Management Approach of Full Amount } \\
\text { Indemnificatory Acquisition of Renewable Energy }\end{array}$ & 2016 & $\begin{array}{l}\text { Identity the definition, main body of responsibility, scope of } \\
\text { protection and compensation methods }\end{array}$ \\
\hline Thirteen Five-year Plan of Renewable Energy & 2016 & $\begin{array}{l}\text { By the end of 2020, establish equal platform competition } \\
\text { situation between power prices of wind power and local } \\
\text { coal-fired power and implement wind/solar hybrid power } \\
\text { generation demonstration base }\end{array}$ \\
\hline Suggestion on Energy Work 2017 & 2017 & $\begin{array}{l}\text { Optimize wind power construction distribution and lean on } \\
\text { Middle East and South areas, restrict new on-grid projects in } \\
\text { areas with high wind rejection, and fasten R\&D of offshore } \\
\text { wind power }\end{array}$ \\
\hline $\begin{array}{l}\text { Implementation Plan of Solving Water/Wind/Solar } \\
\text { Power Rejection Problems }\end{array}$ & 2017 & $\begin{array}{l}\text { Update renewable energy rejection situation in relative areas } \\
\text { by } 2017 \text { and effectively solve renewable energy rejection } \\
\text { problems across the country by } 2020\end{array}$ \\
\hline $\begin{array}{l}\text { Opinions on Deepening the Reform of the } \\
\text { Price Mechanism }\end{array}$ & 2017 & $\begin{array}{l}\text { Promote price mechanism of renewable power and keep } \\
\text { on-grid price of wind power consistent with that of coal-fired } \\
\text { power generation }\end{array}$ \\
\hline $\begin{array}{l}\text { Interim Measures for Development and Construction } \\
\text { of Decentralized Wind Power Projects }\end{array}$ & 2018 & $\begin{array}{l}\text { Accelerate the development and improve the management } \\
\text { process and working mechanism of decentralized wind power }\end{array}$ \\
\hline
\end{tabular}

Table 4. Financial \& tax incentives of wind power in China.

\begin{tabular}{lll}
\hline Financial \& Tax Incentives & Year & Key Points \\
\hline $\begin{array}{l}\text { Notice on Favorable Corporate Income Tax List of } \\
\text { Public Infrastructure Projects (2008) }\end{array}$ & 2008 & $\begin{array}{l}\text { Tax exemption in first three years and tax halving in second } \\
\text { three years of wind power firms }\end{array}$ \\
\hline $\begin{array}{l}\text { Notice on the Taxation of the Comprehensive } \\
\text { Utilization of Resources and Other Value-additional }\end{array}$ & 2008 & $\begin{array}{l}\text { Refund 50\% of value-added tax imposed by power generated } \\
\text { with wind power }\end{array}$ \\
\hline $\begin{array}{l}\text { Provisional Measures for Energy Saving and } \\
\begin{array}{l}\text { Emission Reduction Funds in the Central } \\
\text { State-owned Capital Operation Budget }\end{array}\end{array}$ & 2011 & $\begin{array}{l}\text { Income tax exemption for finance less than 20\% of actual } \\
\text { investment obtained of offshore wind power projects }\end{array}$ \\
\hline Notice on Value-adding Taxation of Wind Power & 2015 & $\begin{array}{l}\text { Refund 50\% of value-added tax imposed by power products } \\
\text { of taxpayer using wind power generated by itself }\end{array}$ \\
\hline
\end{tabular}

\subsection{Technology}

\subsubsection{Energy Storage}

According to International Energy Agency, energy storage (ES) technologies absorb energy and store it for a period of time before releasing it to supply energy or power services [77]. ES plays a significant role in value creation and innovation in the wind power industry value chain by providing the following services: (i) improving energy system efficiency, (ii) integrating variable renewable energy, (iii) supporting greater production of energy where it is consumed, (iv) improving energy access ability, and (v) enhancing the stability, flexibility, reliability, and resilience of electricity grid [43]. The current power grid in China was originally designed for traditional power, but the impact of wind power on the grid requires additional peak adjustment units (e.g., ES units) based on the aforementioned functions of ES. Meanwhile, ES technologies will help us to improve uneven distribution between rich wind resource areas and heavy electricity load areas [13]. Therefore, the Chinese government has made laws, regulations, and programs for renewable energy involving ES since 2005. The Thirteen Five-Year Plan of Energy Technology Innovation ([2016] No. 397) pointed out that China would emphasize the research on new high-efficiency battery ES technology in the period from 2016 to 
2020 [78], while Opinions on Promoting Energy Storage Technology and Industry Development ([2017] No. 1701) considered ES as important components and key support technologies of smart grid construction, energy systems with high penetration of renewable energy, and "Internet +" intelligent energy systems [79].

\subsubsection{Constructions of UHV Grids}

The UHV grid system in China is being developed with amazing speed, and has attracted global attention. Indeed, $1100 \mathrm{kV}$ extra-high voltage transmission lines are under construction to enhance the energy exchange and transmission ability of whole country. On 8 January 2018, $\pm 800 \mathrm{kV}$ DC power transmission technology won the Grand Prize of 2017 National Science and Technology Progress Award of China for its high voltage level, large transmission capacity, long transmission distance, and advanced technique level. Meanwhile, core technology equipment of the DC power grid, $\pm 500 \mathrm{kV}$ DC power transmission lines research and development, and new types of UHV AC power transmission technologies are encouraged at the national level. The State Grid of China has completed the "Eight ACs and Ten DCs" UHV power transmission projects crossing the "Three-Norths" areas and coastal cities by 2017, which improve wind power grid connections and the consumption abilities of the whole country. These transmission lines are shown in Figure 15 and Table 5.

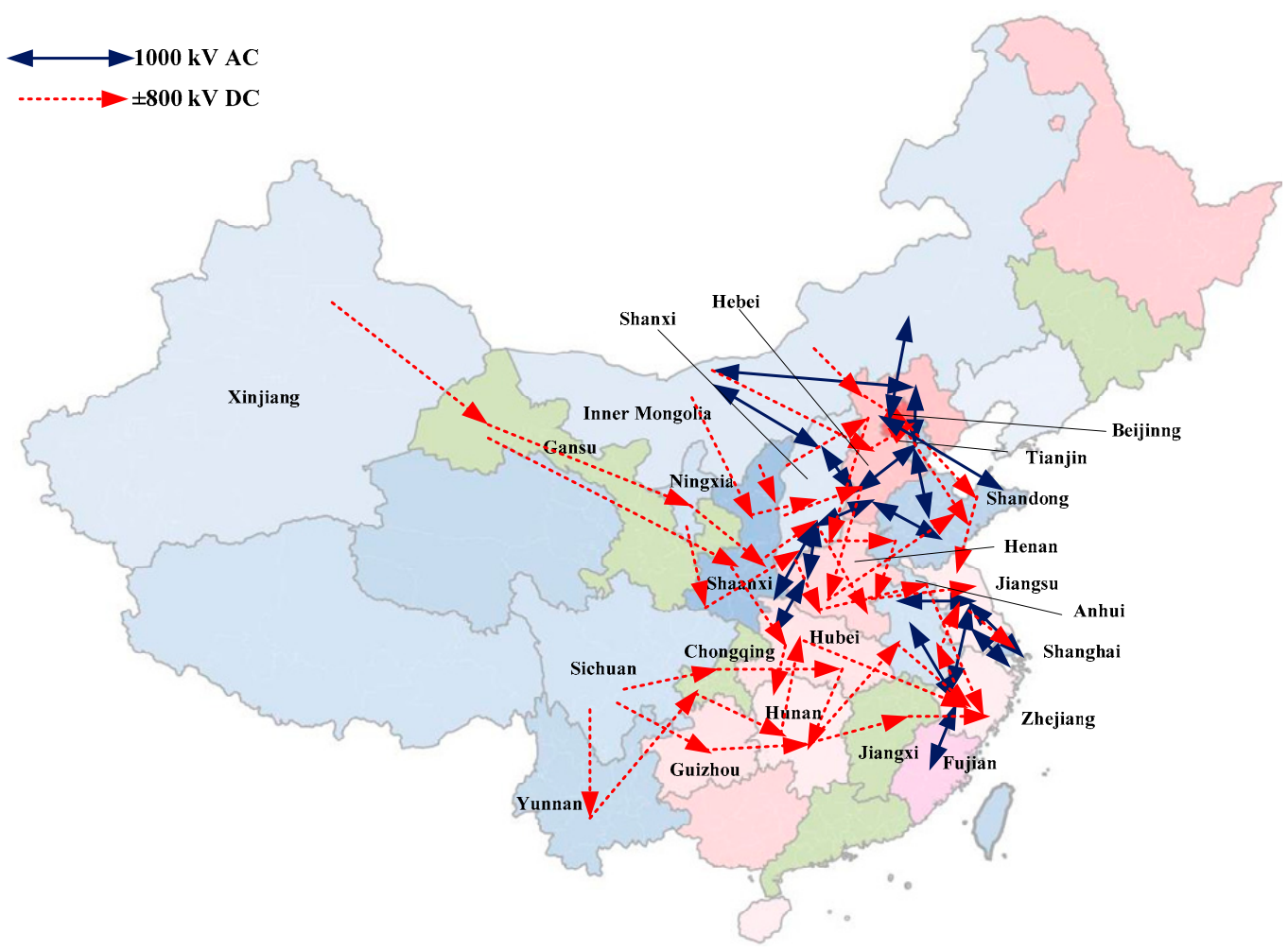

Figure 15. UHV power transmission lines of State Grid by 2017. 
Table 5. "Eight ACs and Ten DCs" UHV power transmission projects of the State Grid.

\begin{tabular}{|c|c|c|c|c|c|}
\hline No & Projects & Types & $\begin{array}{l}\text { Start } \\
\text { Time }\end{array}$ & $\begin{array}{l}\text { Operation } \\
\text { Time }\end{array}$ & Crossing Provinces \\
\hline 1 & $\begin{array}{c}\text { Southeast } \\
\text { Shanxi-Nanyang-Jingmen }\end{array}$ & $1000 \mathrm{kV} \mathrm{AC}$ & 2006 & 2009 & Shanxi-Henan-Hubei \\
\hline 2 & $\begin{array}{l}\text { South Anhui-North } \\
\text { Zhejiang-Shanghai }\end{array}$ & $1000 \mathrm{kV} \mathrm{AC}$ & 2011 & 2013 & Anhui-Zhejiang-Jiangsu-Shanghai \\
\hline 3 & North Zhejiang-Fuzhou & $1000 \mathrm{kV} \mathrm{AC}$ & 2013 & 2014 & Zhejiang-Fujian \\
\hline 4 & $\begin{array}{c}\text { South } \\
\text { Anhui-Nanjing-Shanghai }\end{array}$ & $1000 \mathrm{kV}$ AC & 2014 & 2016 & Anhui-Jiangsu-Shanghai \\
\hline 5 & Ximeng-Shangdong & $1000 \mathrm{kV} \mathrm{AC}$ & 2014 & 2016 & Inner Mongolia-Hebei-Tianjin-Shandong \\
\hline 6 & $\begin{array}{c}\text { West Inner } \\
\text { Mongolia-Shandong }\end{array}$ & $1000 \mathrm{kV}$ AC & 2015 & 2016 & Inner Mongolia-Shanxi-Hebei-Tianjin \\
\hline 7 & Xiangiiaba-Shanghai & $800 \mathrm{kV} \mathrm{DC}$ & 2007 & 2010 & $\begin{array}{l}\text { Sichuan-Chongqing-Hebei-Hunan- } \\
\text { Anhui-Zhejiang-Jiangsu-Shanghai }\end{array}$ \\
\hline 8 & Jinping-south Jiangsu & $800 \mathrm{kV} \mathrm{DC}$ & 2009 & 2012 & $\begin{array}{l}\text { Sichuan-Yunnan-Chongqing-Hunan- } \\
\text { Hubei-Zhejiang-Anhui-Jiangsu }\end{array}$ \\
\hline 9 & South Hami-Zhengzhou & $800 \mathrm{kV} \mathrm{DC}$ & 2012 & 2014 & $\begin{array}{l}\text { Xinjiang-Gansu-Ningxia-Shaanxi- } \\
\text { Shanxi-Zhejiang }\end{array}$ \\
\hline 10 & Xiluodu-Jinhua & $800 \mathrm{kV}$ DC & 2012 & 2014 & Sichuan-Guizhou-Hunan- Jiangxi-Zhejiang \\
\hline 11 & East Ningxia-Zhejiang & $800 \mathrm{kV} \mathrm{DC}$ & 2014 & 2016 & $\begin{array}{l}\text { Ningxia-Shaanxi-Shanxi-Henan- } \\
\text { Anhui-Zhejiang }\end{array}$ \\
\hline 12 & Hengyu-Huaifang & $1000 \mathrm{kV}$ AC & 2015 & 2017 & Shaanxi-Shanxi-Hebei-Shandong \\
\hline 13 & Jiuquan-Hunan & $800 \mathrm{kV} \mathrm{DC}$ & 2015 & 2017 & Gansu-Shanxi-Chongqing- Hubei-Hunan \\
\hline 14 & North Shanxi-Jiangsu & $800 \mathrm{kV} \mathrm{DC}$ & 2015 & 2017 & $\begin{array}{l}\text { Shanxi-Hebei-Henan-Shandong- } \\
\text { Anhui-Jiangsu }\end{array}$ \\
\hline 15 & Shanghaimiao-Shandong & $800 \mathrm{kV} \mathrm{DC}$ & 2015 & 2017 & $\begin{array}{l}\text { Inner Mongolia-Shaanxi-Shanxi-Hebei- } \\
\text { Henan-Shandong }\end{array}$ \\
\hline 16 & Ximeng-Taizhou & $800 \mathrm{kV} \mathrm{DC}$ & 2015 & 2017 & $\begin{array}{c}\text { Inner } \\
\text { Mongolia-Hebei-Tianjin-Shandong-Jiangsu }\end{array}$ \\
\hline 17 & Zhalute-Qingzhou & $800 \mathrm{kV}$ DC & 2016 & 2017 & Inner Mongolia-Hebei-Tianjin-Shandong \\
\hline 18 & Ximeng-Shengli & $1000 \mathrm{kV} \mathrm{AC}$ & 2016 & 2017 & Inner Mongolia-Beijing-Shandong \\
\hline
\end{tabular}

\section{Discussion}

\subsection{Comparison Discussion}

Focused on the worldwide wind power development situation, countries such as China, United States, and India, have achieved outstanding performance; Japan is a notable exception. Even though Japan has limited wind resources compared to other Asian countries, its installed capacity ranked 4th in the world in 2016 ( 3 GW) [80]. To further discuss the value chain of the Chinese wind power industry, a comparison with Japan using a modified diamond model is presented in this section.

(1) Factor condition. Wind power in Japan is restricted by two natural factors. For onshore, geographical distribution of wind resources is quite uneven across Japan, since wind energy resources are concentrated in the Hokkaido, Tohoku, and Kyushu EPCO regions, while the demand centers are located somewhere else [81]; this challenge remains the same with resource distribution in China. For offshore, Japan owns rich offshore wind resources, but more than $1600 \mathrm{GW}$ potential wind energy is located in ocean with depths greater than $100 \mathrm{~m}$. China is also enhancing offshore wind power development with support from the government and wind turbine companies.

(2) Demand condition. Although wind power in China and Japan both confront the difficulty of grid-connection and transmission, Chinese generated wind power has increased from 5.5 TWh in 2006 to 286.1 TWh in 2017, but Japanese generated wind power increased only from 2.7 TWh in 2006 to 5.7 TWh in 2017, an extremely low rate. Moreover, one significant bottleneck of 
demand conditions in Japan is the social acceptance issue, which means that wind projects are not supported by local communities, because past projects in the early stage brought no benefits but created noise and landscape disturbance [81]. Nevertheless, both the Chinese and Japanese governments are applying certain regulations and policies to improve the demand conditions of domestic wind power.

(3) Related and support departments. In contrast to China's booming wind turbine manufacturing industry, the wind power domestic market in Japan is small, because of immature market attractiveness and scale. Over the years, the Japanese power generation supply chain from resource acquisition to power generation to transmission and distribution has been monopolized by utilities [82] who show little interest in wind power projects with high construction costs, and intermittence and transmission problems. Moreover, the corresponding supportive policies of national government have not yielded the expected effects and response. In contrast, the support departments in China effectively respond to national policy, which improves the development process.

(4) Firm strategies, structures and rivalries. Compared with wind power, nuclear power develops fast and occupies a key position in the Japanese energy structure. After the Great East Earthquake, Tsunami, and Fukushima Nuclear Plant disaster, Japan has started to pay more attention to wind power. The grid access problem is jointly faced by the Chinese and Japanese wind industries, and measures to handle intermittence and transmission issues are being explored at the same time. Offshore wind power is also popular in both Japan and China, and floating wind power technology has been developed in recent years with more attention in Japan. Japan has excellent performance in ES industry development. Japan's NGK is the world's first and only company to successfully commercialize sodium-sulfur batteries; its products account for the majority of the world's chemical energy storage market. In this regard, China also shows strong interest in the ES industry.

(5) Government and opportunity. Compared with China's price and non-price policies, and large-scale financial support, Japan pays less attention to wind power. Japan has published a series of supportive policies, including the Sunshine Program, the Moonlight Program, the new Sunshine Program, and the Feed-In Tariff mechanism. But the budget for wind power in these policies was far smaller than that of solar or geothermal. The fifth Energy Basic Plan issued by the Ministry of Economy, Trade, and Industry in July 2018 reflects Japanese determination for renewable energy development, in which wind power might play a key role.

(6) Technology. China has a considerable number of wind turbine manufactures, and the installed capacity leads the world; however, China lacks the corresponding technical innovation and necessary patents, which is a high value-adding sector in the value chain. As the primary researcher of renewable energy, Japan owns a bunch of independent innovations and patents. As for new technical projects, such as offshore floating wind power, Japan also conducts numerous studies. The Japanese government has supported the development of ES technologies, and has obtained fine achievements. China should also increase the R\&D strength of wind power and related technologies.

\subsection{Measurement Discussion}

According to a comprehensive analysis about the value chain in Section 3, the development route of the wind power industry in China in recent years has focused on installed capacity and wind farm scales instead of the overall wind power industry, i.e., wind farms, power transmission, power distribution, power selling, ES firms, end users, and so on. However, the value creation and innovation effect of the wind power value chain should combine every spot in the value chain, and search for a symbiotic effect. In other words, a gap exists between actual performance and the expected wind power industry value chain in China. To reduce the gap, this section will provide the appropriate measurements; our framework is shown in Figure 16. 


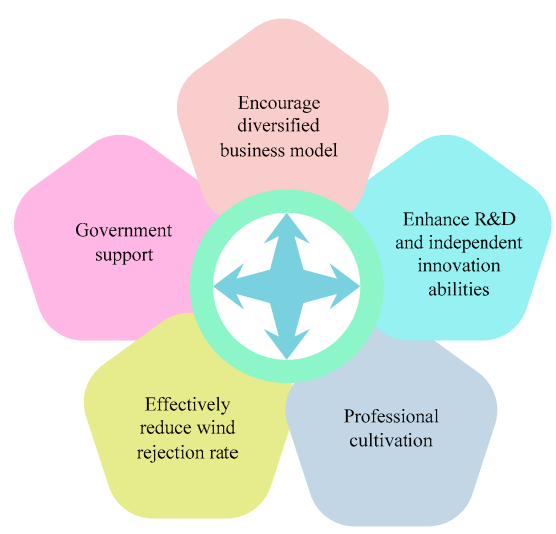

Figure 16. Framework for improving value creation and the innovation effect of the value chain.

(1) Encourage a diversified business model. The power system in China is dominated by the State and China Southern Power Grids, of which wind power occupies a small proportion in the energy consumption structure. To increase the value creation and innovation effect of the whole value chain, we should keep our eyes on an overall level. As part of the high value-adding section, a diversified business model should be adopted. According to Opinions about Further Deepening the Reform of Electric Power System ([2015] No. 9), issued by the State Council, a diversified business model including integrating renewable power with traditional power, cross-regional energy complementarity, power system optimization, and heat supply using renewable energy would be adopted. Wind power development and operations would be open to social capital with public-private partnerships (PPPs). End users can participate in wind power system operations as the investors and promotes of wind power grid connections and industrial development.

(2) Enhance R\&D and independent innovation abilities. As another part of the high value-adding section, improvements in $R \& D$ and independent innovation abilities will effectively increase the value creation and innovation effects of the overall value chain of wind power. Challenges such as shortages of suitable and national technical codes for wind power integration, quality problem of wind power equipment, reliance on key design techniques of European and American companies, and an imperfect certification system for wind turbines require core technology $R \& D$ and improvements in the capacity of independent innovation. China should apply Big data, $3 \mathrm{D}$ printing, and other intelligent manufacturing technologies in promoting the performance and intelligence levels of the wind power industry, break though design and manufacturing technology for $10 \mathrm{MW}$ level, high-capacity wind turbines and key components, and encourage the application of innovative technology to improve quality and reduce operation costs.

(3) Professional cultivation. The shortage of wind power professional talent is one of the main factors hindering the value adding effect of the wind power industry in China. At present, only 16 universities in China have established Bachelor's degrees in wind power engineering, and talent cultivation in Chinese universities takes at least 4 years; as such, professionals are in short supply. The Thirteen Five-Year Plan for Wind Power Development ([2016] No. 314) laid out a plan to increase the employment scale of the wind power industry to 0.8 million people, with 0.3 million newly-added employees by 2020 [63]. This plan challenges the current talent situation, and raises nationwide professional cultivation needs. China should train qualified professionals by cooperation with the state, society, universities, research institutions, and enterprises.

(4) Effectively reduce wind rejection rate. To avoid resource waste and value loss, electricity generated with wind power should be consumed in surrounding regions with diversified utilization forms, namely "elimination on the spot", and allocated with cross-region and cross-province transmission lines to increase the proportion of wind power in the energy consumption structure. Meanwhile, off-grid wind power can be effectively stored with ES equipment and consumed in diversified ways [30]. 
(5) Government support. Whether or not the government can make a difference in the policy incentives and the legal environment design of wind power development is a crucial question. At the top stage of the value creation and innovation of the wind power industry value chain, the government should provide suggestions on how to use market leverage and how to design, establish, and guide market-oriented institutions, mechanisms, policies and measures, laws and regulations, and supervision through "visible hands". The wind power rejection phenomenon should be improved by related development plans and financial \& economic incentives; additionally, ES technologies should be further promoted to help grid connection of wind power and reduce the corresponding influence on the grid, and power generation and selling firms and power market development and operation should be encouraged and supported, demand side response technologies and regulations for increasing wind power consumption should be promoted and determined. None of these can be accomplished without government support.

\section{Conclusions}

Driven by continuous and staunch support of government support, China's wind power industry has achieved outstanding success in installed capacity scales, wind turbine and components manufacturing, and cost reduction. With global sustainable development requirements and industrial development, considering the wind power industry as a whole and improving its overall value effect become urgent. Therefore, the paper aims at constructing a wind power industry value chain model and reviewing its comprehensive status with a modified diamond model to distinguish high value-adding sectors, and to enhance the value effect of the value chain concerning the actual situation of the Chinese wind power industry. The main findings of the paper include the following:

(1) The Chinese wind power industry develops fast in installed capacity scale and turbine and components manufacturing, but the high value-adding sectors require attention.

(2) A novel value chain model covering both low and high value-adding sectors was conducted.

(3) For the comprehensive analysis with the diamond model: (i) a factor condition analysis showed that China was experiencing domestic energy structure adjustment and would increase the proportion of wind power in its energy consumption structure. (ii) China had increasing demand for wind power, and the consumption goal was guaranteed by the government; however, serious wind rejection brought about the need for value chain integration. (iii) Except for power generation and transmission subjects, increment power distribution subjects, ES subjects, and power selling subjects with promising value efficiency have undergone simultaneous rapid development. (iv) As for firm strategies, structures, and rivalries, more liberalized market modes were able to stimulate the value chain. (v) Government support laid robust foundation for value chain development. (vi) As a high value-adding sector, ES technology and the UHV grid had significant performance in China.

(4) A comparitive analysis of the value chains in Japan and China was presented; the results showed that wind power in China developed fast, while Japan had a relatively slow development rate. However, Japan excelled in innovative technologies and patents. In addition, measures were suggested to help increase value creation and the innovation effect of the wind power value chain.

The significant finding of this paper is that the comprehensive analysis based on the constructed value chain model reveals that the overall value effect of China's wind power industry value chain needs further promotion in both the low and high value-adding sectors. Motivated by a desirable value efficiency of the expected wind power value chain and the potential value-adding function of the current situation, our study helps to integrate the current wind power industry value chain and improve its symbiosis awareness from the angle of value theory; our work is therefore important. However, the constructed value chain involves various subjects with different roles in improving 
the overall value effect, so a collaboration strategy of subjects and their qualitative and quantitative impacts should be discussed in future work.

Author Contributions: Data curation, J.L. and Q.W.; Formal analysis, J.L. and Q.W.; Funding acquisition, J.L.; Methodology, Q.W.; Writing—original draft, Q.W.; Writing—review \& editing, Q.W., Q.D. and C.L.

Acknowledgments: This research was funded by [National Natural Science Foundation of China] grant number [71771085], and The APC was funded by [National Natural Science Foundation of China] grant number [71771085].

Conflicts of Interest: The authors declare no conflict of interest.

\section{References}

1. Han, X.; Zhou, M.; Li, G.; Lee, K.Y. Stochastic Unit Commitment of Wind-Integrated Power System Considering Air-Conditioning Loads for Demand Response. Appl. Sci. 2017, 7, 1154. [CrossRef]

2. He, Y.; $\mathrm{Xu}, \mathrm{Y}$.; Pang, Y.; Tian, $\mathrm{H} . ; \mathrm{Wu}, \mathrm{R}$. A regulatory policy to promote renewable energy consumption in China: Review and future evolutionary path. Renew. Energy 2016, 89, 695-705. [CrossRef]

3. Liu, J.; He, D. Profit Allocation of Hybrid Power System Planning in Energy Internet: A Cooperative Game Study. Sustainability 2018, 10, 388. [CrossRef]

4. Dong, C.; Qi, Y.; Dong, W.; Lu, X.; Liu, T.; Qian, S. Decomposing driving factors for wind curtailment under economic new normal in China. Appl. Energy 2018, 217, 178-188. [CrossRef]

5. Golkhandan, R.K.; Aghaebrahimi, M.R.; Farshad, M. Control Strategies for Enhancing Frequency Stability by DFIGs in a Power System with High Percentage of Wind Power Penetration. Appl. Sci. 2017, 7, 1140. [CrossRef]

6. Ning, J.; Tang, Y.; Gao, B. A Time-Varying Potential-Based Demand Response Method for Mitigating the Impacts of Wind Power Forecasting Errors. Appl. Sci. 2017, 7, 1132. [CrossRef]

7. Feng, Y.; Lin, H.; Ho, S.L.; Yan, J.; Dong, J.; Fang, S.; Huang, Y. Overview of wind power generation in China: Status and development. Renew. Sustain. Energy Rev. 2015, 50, 847-858. [CrossRef]

8. Yang, J.; Liu, Q.; Li, X.; Cui, X. Overview of Wind Power in China: Status and Future. Sustainability 2017, 9, 1454. [CrossRef]

9. Huenteler, J.; Tang, T.; Chan, G.; Anadon, L.D. Why is China's wind power generation not living up to its potential? Environ. Res. Lett. 2018, 13, 044001. [CrossRef]

10. National Energy Administration (NEA). Wind Power On-Grid Operation Situation of 2017. Available online: http://www.gov.cn/xinwen/2018-02/02/content_5263096.htm (accessed on 19 July 2018).

11. Zhao, Z.; Tian, Y.; Zillante, G. Modeling and evaluation of the wind power industry chain: A China study. Renew. Sustain. Energy Rev. 2014, 31, 397-406. [CrossRef]

12. Li, C.-B.; Chen, H.-Y.; Zhu, J.; Zuo, J.; Zillante, G.; Zhao, Z.-Y. Comprehensive assessment of flexibility of the wind power industry chain. Renew. Energy 2015, 74, 18-26. [CrossRef]

13. Liu, Y.; Ren, L.; Li, Y.; Zhao, X. The industrial performance of wind power industry in China. Renew. Sustain. Energy Rev. 2015, 43, 644-655. [CrossRef]

14. Zhang, Y.; Tang, N.; Niu, Y.; Du, X. Wind energy rejection in China: Current status, reasons and perspectives. Renew. Sustain. Energy Rev. 2016, 66, 322-344. [CrossRef]

15. Hu, Y.; Huang, W.; Wang, J.; Chen, S.; Zhang, J. Current status, challenges, and perspectives of Sichuan's renewable energy development in Southwest China. Renew. Sustain. Energy Rev. 2016, 57, 1373-1385. [CrossRef]

16. Zhang, S.; Li, X. Large scale wind power integration in China: Analysis from a policy perspective. Renew. Sustain. Energy Rev. 2012, 16, 1110-1115. [CrossRef]

17. China's Industry Information Website. China's Wind Power Industry Operation Situation Analysis of 2017. Available online: http:/ / www.chyxx.com/industry/201707/544779.html (accessed on 19 July 2018).

18. Geng, W.; Ming, Z.; Lilin, P.; Ximei, L.; Bo, L.; Jinhui, D. China's new energy development: Status, constraints and reforms. Renew. Sustain. Energy Rev. 2016, 53, 885-896. [CrossRef]

19. Zhao, Z.-Y.; Wu, P.-H.; Xia, B.; Skitmore, M. Development route of the wind power industry in China. Renew. Sustain. Energy Rev. 2014, 34, 1-7. [CrossRef]

20. Zhao, X.; Wei, Y.; Ren, L. Has the turning point of China's wind power industry really come? Renew. Sustain. Energy Rev. 2015, 41, 1413-1422. [CrossRef] 
21. Li, Y.; Li, Y.; Ji, P.; Yang, J. Development of energy storage industry in China: A technical and economic point of review. Renew. Sustain. Energy Rev. 2015, 49, 805-812. [CrossRef]

22. Liu, J.; He, D.; Long, T. Study on value creation effect of wind power industry value chain based on system dynamics. Sci. Technol. Manag. Res. 2017, 243-248.

23. Lam, L.T.; Branstetter, L.; Azevedo, I.M.L. China's wind industry: Leading in deployment, lagging in innovation. Energy Policy 2017, 106, 588-599. [CrossRef]

24. Sun, S.; Liu, F.; Xue, S.; Zeng, M.; Zeng, F. Review on wind power development in China: Current situation and improvement strategies to realize future development. Renew. Sustain. Energy Rev. 2015, 45, 589-599. [CrossRef]

25. Yuan, J.; Xu, Y.; Zhang, X.; Hu, Z.; Xu, M. China's 2020 clean energy target: Consistency, pathways and policy implications. Energy Policy 2014, 65, 692-700. [CrossRef]

26. Xingang, Z.; Jieyu, W.; Xiaomeng, L.; Pingkuo, L. China's wind, biomass and solar power generation: What the situation tells us? Renew. Sustain. Energy Rev. 2012, 16, 6173-6182. [CrossRef]

27. Ming, Z.; Kun, Z.; Jun, D. Overall review of China's wind power industry: Status quo, existing problems and perspective for future development. Renew. Sustain. Energy Rev. 2013, 24, 379-386. [CrossRef]

28. Zhao, Z.Y.; Hu, J.; Zuo, J. Performance of wind power industry development in China: A Diamond Model study. Renew. Energy 2009, 34, 2883-2891. [CrossRef]

29. Sahu, B.K. Wind energy developments and policies in China: A short review. Renew. Sustain. Energy Rev. 2018, 81, 1393-1405. [CrossRef]

30. Liu, J.; He, D.; Long, T. Research on Data Integration of Wind Power to Meet Energy Internet Demand. Power Syst. Technol. 2017, 978-984.

31. Hasan, N.S.; Hassan, M.Y.; Majid, M.S.; Rahman, H.A. Review of storage schemes for wind energy systems. Renew. Sustain. Energy Rev. 2013, 21, 237-247. [CrossRef]

32. Zhao, Z.-Y.; Zhu, J.; Zuo, J. Sustainable development of the wind power industry in a complex environment: A flexibility study. Energy Policy 2014, 75, 392-397. [CrossRef]

33. Kang, B.; Jang, K.; Park, S.; Choi, M.; Park, S. Energy Storage System Control Algorithm by Operating Target Power to Improve Energy Sustainability of Smart Home. Sustainability 2018, 10, 236. [CrossRef]

34. Shi, N.; Luo, Y. Energy Storage System Sizing Based on a Reliability Assessment of Power Systems Integrated with Wind Power. Sustainability 2017, 9, 395. [CrossRef]

35. You, P.; Guo, S.; Zhao, H.; Zhao, H. Operation Performance Evaluation of Power Grid Enterprise Using a Hybrid BWM-TOPSIS Method. Sustainability 2017, 9, 2329. [CrossRef]

36. Zhao, H.; Zhao, H.; Guo, S. Short-Term Wind Electric Power Forecasting Using a Novel Multi-Stage Intelligent Algorithm. Sustainability 2018, 10, 881. [CrossRef]

37. Mou, D. Wind Power Development and Energy Storage under China's Electricity Market Reform-A Case Study of Fujian Province. Sustainability 2018, 10, 298. [CrossRef]

38. Alhmoud, L.; Wang, B. A review of the state-of-the-art in wind-energy reliability analysis. Renew. Sustain. Energy Rev. 2018, 81, 1643-1651. [CrossRef]

39. Hung, T.-C.; Chong, J.; Chan, K.-Y. Reducing uncertainty accumulation in wind-integrated electrical grid. Energy 2017, 141, 1072-1083. [CrossRef]

40. Zhao, Z.-Y.; Zhu, J.; Zuo, J. Flexibility of wind power industry chain for environmental turbulence: A matching model study. Renew. Energy 2015, 83, 375-383. [CrossRef]

41. Yuan, J.; Sun, S.; Shen, J.; Xu, Y.; Zhao, C. Wind power supply chain in China. Renew. Sustain. Energy Rev. 2014, 39, 356-369. [CrossRef]

42. Zhao, Z.; Zhang, S.; Zuo, J. A critical analysis of the photovoltaic power industry in China-From diamond model to gear model. Renew. Sustain. Energy Rev. 2011, 15, 4963-4971. [CrossRef]

43. Wu, Y.; Xiao, X.; Song, Z. Competitiveness analysis of coal industry in China: A diamond model study. Resour. Policy 2017, 52, 39-53. [CrossRef]

44. Fainshmidt, S.; Smith, A.; Judge, W.Q. National Competitiveness and Porter's Diamond Model: The Role of Mne Penetration and Governance Quality. Glob. Strateg. J. 2016, 6, 81-104. [CrossRef]

45. Nam, S.-J. Exploring Success Factors of Night Markets: Utilizing the Diamond Model. Int. J. Ind. Distrib. Bus. 2017, 8, 33-38. [CrossRef]

46. Fang, K.; Zhou, Y.; Wang, S.; Ye, R.; Guo, S. Assessing national renewable energy competitiveness of the G20: A revised Porter's Diamond Model. Renew. Sustain. Energy Rev. 2018, 93, 719-731. [CrossRef] 
47. Porter, M.E. Competitive Strategy; HuaXia Press: Beijing, China, 2005.

48. Ketterer, J.C. The impact of wind power generation on the electricity price in Germany. Energy Econ. 2014, 44, 270-280. [CrossRef]

49. Yuan, X.; Chen, C.; Yuan, Y.; Huang, Y.; Tan, Q. Short-term wind power prediction based on LSSVM-GSA model. Energy Convers. Manag. 2015, 101, 393-401. [CrossRef]

50. Govindan, K.; Khodaverdi, R.; Jafarian, A. A fuzzy multi criteria approach for measuring sustainability performance of a supplier based on triple bottom line approach. J. Clean. Prod. 2013, 47, 345-354. [CrossRef]

51. Herrero-Novoa, C.; Pérez, I.A.; Sánchez, M.L.; García, M.Á.; Pardo, N.; Fernández-Duque, B. Wind speed description and power density in northern Spain. Energy 2017, 138, 967-976. [CrossRef]

52. Zerrahn, A. Wind Power and Externalities. Ecol. Econ. 2017, 141, 245-260. [CrossRef]

53. Chinese Wind Energy Association (CWEA). Available online: http://www.cwea.org.cn/\#4thpage (accessed on 11 December 2017).

54. Chung, T. A Study on Logistics Cluster Competitiveness among Asia Main Countries using the Porter's Diamond Model. Asian J. Shipp. Logist. 2016, 32, 257-264. [CrossRef]

55. Yoon, J.I.; Kim, Y.J. A diamond Model approach to the Competitiveness Analysis of Air Cargo Industry of Korea, China and Japan. Korean J. Logist. 2016, 24, 39-62.

56. Kharub, M.; Sharma, R. Comparative analyses of competitive advantage using Porter diamond model (the case of MSMEs in Himachal Pradesh). Compet. Rev. 2017, 27, 132-160. [CrossRef]

57. Dong, K.-Y.; Sun, R.-J.; Li, H.; Jiang, H.-D. A review of China's energy consumption structure and outlook based on a long-range energy alternatives modeling tool. Pet. Sci. 2017, 14, 214-227. [CrossRef]

58. BP. Statistical Review of World Energy. 2017. Available online: https://www.bp.com/en/global/corporate/ energy-economics/statistical-review-of-world-energy.html (accessed on 19 July 2018).

59. BP. Statistical Review of World Energy. 2018. Available online: https:/ / www.bp.com/ (accessed on 20 July 2018).

60. National Development and Reform Commission; National Energy Administration. Energy Production and Consumption Reform Strategy (2016-2030). Available online: http:/ / www.ndrc.gov.cn/zcfb/zcfbtz/ 201704/t20170425_845284.html (accessed on 19 July 2017).

61. Chinese Industry Information. Energy Consumption Structure Prediction. Available online: http:/ / www. chyxx.com/industry/201612/474936.html (accessed on 20 July 2018).

62. National Energy Administration (NEA). Wind Power Operation Situation of China. 2016. Available online: http:/ / www.nea.gov.cn/2017-01/26/c_136014615.htm (accessed on 19 September 2018).

63. National Energy Administration. The Thirteen Five-Year Plan for Wind Power Development. Available online: http:/ / www.nea.gov.cn/2016-11/29/c_135867633.htm (accessed on 20 June 2018).

64. China Electricity Council. National Energy Consumption of 2008. Available online: http://www.cec.org.cn/ yaowenkuaidi/2010-11-27/29989.html (accessed on 18 September 2018).

65. People.cn. National Energy Consumption of 2007. Available online: http:/ / pic.people.com.cn/GB/73697/ 7154328.html (accessed on 18 September 2018).

66. The Central People's Government of the People's Republic of China. Wind Power Generation of China. 2010. Available online: http:/ / tech.hqew.com/news_627250 (accessed on 19 September 2018).

67. Luo, G.; Li, Y.; Tang, W.; Wei, X. Wind curtailment of China's wind power operation: Evolution, causes and solutions. Renew. Sustain. Energy Rev. 2016, 53, 1190-1201. [CrossRef]

68. ESCN. Wind Curtialment Rate of China. 2015. Available online: http://www.escn.com.cn/news/show309585.html (accessed on 19 September 2018).

69. Fan, X.; Wang, W.; Shi, R.; Li, F. Analysis and countermeasures of wind power curtailment in China. Renew. Sustain. Energy Rev. 2015, 52, 1429-1436. [CrossRef]

70. Xu, F.; Liu, J.; Lin, S.; Dai, Q.; Li, C. A multi-objective optimization model of hybrid energy storage system for non-grid-connected wind power: A case study in China. Energy 2018, 163, 585-603. [CrossRef]

71. Polaris Power Grid. Statistics of Wind Power Installed Capacity of China in 2017. Available online: http: / / news.bjx.com.cn/html/20180403/889653-2.shtml (accessed on 20 July 2018).

72. National Development and Reform Commission; National Energy Administration. Notice about Second Batch of Pilot Increment Power Distribution Reform ([2017] No. 2010). Available online: http:/ /www.ndrc. gov.cn/gzdt/201711/t20171124_867809.html (accessed on 28 December 2017). 
73. National Development and Reform Commission; National Energy Administration. Notice about Pilot Increment Power Distribution Reform ([2016] No. 2480). Available online: http:/ / www.ndrc.gov.cn/zcfb/ zcfbtz/201612/t20161201_828814.html (accessed on 28 December 2017).

74. Energy Storage Network of China. Report on Energy Storage of Top 500 Enterprise of the World. 2016. Available online: http:/ / www.escn.com.cn/news/show-372314.html (accessed on 28 December 2017).

75. Wang, H. Competitive and Influencing Factors Research on Chinese Wind Power Industry; Jiangnan University: Wuxi, China, 2014.

76. CPC Central Committee; State Council of China. Opinions of the Central Committee of the Communist Party of China and the State Council on Further Deepening the Reform of the Electric Power System ([2015] No. 9). Available online: http:/ /tgs.ndrc.gov.cn/_zywj/201601/t20160129_773852.html (accessed on 30 June 2018).

77. International Energy Agency (IEA). Technology Road Map, Energy Storage. Available online: https://www. iea.org (accessed on 4 January 2018).

78. National Energy Administration. Thirteen Five-Year Plan of Energy Technology Innovation ([2016] No. 397). Available online: http:/ / zfxxgk.nea.gov.cn/auto83/201701/t20170113_2490.htm (accessed on 10 December 2017).

79. National Development and Reform Commission. Opinions on Promoting Energy Storage Technology and Industry Development ([2017] No. 1701). Available online: http:/ / www.ndrc.gov.cn/gzdt/201710/ t20171011_863348.html (accessed on 28 June 2018).

80. Bandoc, G.; Prăvălie, R.; Patriche, C.; Degeratu, M. Spatial assessment of wind power potential at global scale. Ageographical approach. J. Clean. Prod. 2018, 200, 1065-1086. [CrossRef]

81. Mizuno, E. Overview of wind energy policy and development in Japan. Renew. Sustain. Energy Rev. 2014, 40, 999-1018. [CrossRef]

82. Valentine, S.V. Japanese wind energy development policy: Grand plan or group think? Energy Policy 2011, 39, 6842-6854. [CrossRef]

(C) 2018 by the authors. Licensee MDPI, Basel, Switzerland. This article is an open access article distributed under the terms and conditions of the Creative Commons Attribution (CC BY) license (http:// creativecommons.org/licenses/by/4.0/). 